\title{
Managerial support, work-family conflict and employee outcomes: an Australian study
}

\section{Phuong Anh Tran, Sadia Mansoor and Muhammad Ali Queensland University of Technology, Brisbane, Australia}

\begin{abstract}
Purpose - Derived from leader-member exchange theory, this study hypothesises the relationships between work-family related managerial support and affective commitment and job satisfaction, and advocates that these relationships are mediated by work-family conflict.

Design/methodology/approach - The model was tested in an Australian manufacturing organisation using survey data from employees, using structural equation modelling in Analysis of Moment Structures (AMOS).

Findings - The findings suggest that enhanced work-family related managerial support will decrease workfamily conflict, eventually enhancing employees' affective commitment and job satisfaction.

Originality/value - This study provides important insights into the impact of managerial support on improvements in employees' work-family conflict, and, in turn, its impact on affective commitment and job satisfaction, in the Australian context.
\end{abstract}

Keywords Managerial support, Work-family conflict, Affective commitment, Job satisfaction

Paper type Research paper

\section{Introduction}

The conflict between work and family has been an important research field due to substantial changes in workforce demographics, such as dual-earner couples and increasing women's workforce participation (Allen et al., 2000; Greenhaus et al., 2012; Odriozola and BaraibarDiez, 2018). "Work-family conflict" (WFC), termed by Greenhaus and Beutell (1985, p. 77), refers to "a form of inter-role conflict in which the role pressures from the work and family domains are mutually incompatible in some respect". WFC is related to work-family interference, which refers to the situation in which participation in the family (work) domain is hindered by participation in the work (family) domain (Tummers and Babette, 2014). WFC can impose direct and indirect costs for an organisation. The former includes involvement and belonging (e.g. turnover, strike or slowdown) and industrial accidents, whereas the latter entails lower levels of job satisfaction and organisational commitment as well as deteriorating the employer-employee relationship (Quick, 2013).

WFC has been found to be negatively associated with employee outcomes in the work domain, including job satisfaction (e.g. Allen et al., 2000; Frone et al., 1992; Gözükara and Çolakoğlu, 2016; Kossek et al., 2011), affective commitment (e.g. Cloninger and Selvarajan, 2015; Qureshi et al., 2019), and well-being (e.g. Chambel et al., 2017; Galletta et al., 2019; Karatepe and Karadas, 2016; Kinman et al., 2017; McDowell et al., 2019). While job satisfaction refers to an individual's enjoyment or positive emotion arising from an evaluation of his or her job and/or job experiences (Locke, 1976), affective commitment is 'the relative strength of an

(C) Phuong Anh Tran, Sadia Mansoor and Muhammad Ali. Published in European Journal of Management and Business Economics. Published by Emerald Publishing Limited. This article is published under the Creative Commons Attribution (CC BY 4.0) licence. Anyone may reproduce, distribute, translate and create derivative works of this article (for both commercial and non-commercial purposes), subject to full attribution to the original publication and authors. The full terms of this licence may be seen at http://creativecommons.org/licences/by/4.0/legalcode
Work-family conflict and employee outcomes

Received 25 March 2020 Revised 31 August 2020 26 November 2020

Accepted 9 April 2021

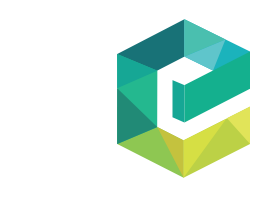

European Journal of Management and Business Economics Vol. 32 No. 1,2023
pp. $73-90$ Emerald Publishing Limited e-ISSN: 2444-8494 p-ISSN: $2444-8451$ DOI 10.1108/EJMBE-03-2020-0056 
EJMBE 32,1

\section{4}

individual's identification with and involvement in a particular organisation' (Mowday et al., 1979, p. 226). Managerial support can elicit satisfaction and affective reactions among employees (Pohl and Galletta, 2017) and has been found to weaken WFC experienced by employees (Karatepe and Kilic, 2007; Frone et al., 1992; Selvarajan et al., 2013). Managerial support is the extent to which managers appreciate employees' contributions, care about their subordinates' well-being and are attentive to employee needs (Eisenberger et al., 2002).

Our study extends work-family research in several ways. First, we test the mediating role of WFC between managerial support and both job satisfaction and affective commitment (see Figure 1). Recent studies have found that the effect of managerial support on job satisfaction was mediated by WFC (Drummond et al., 2017; Hwang and Ramadoss, 2017). A meta-analysis also tested the mediating role of WFC in the relationship between general work support (including support from supervisors, colleagues and organisation) and job satisfaction (Ford et al., 2007). However, little is known about whether WFC mediates the relationship between managerial support and affective commitment (see the Table A1 for key information on relevant studies).

Past studies have mainly explored separate elements of our model. A number of studies found direct effect of work-family related support from managers on job satisfaction (e.g. Babin and Boles, 1996; Charoensukmongkol et al., 2016; Hwang and Ramadoss, 2017; Lapierre et al., 2008; Qureshi et al., 2018) and affective commitment (e.g. Talukder et al., 2018; Thompson et al., 1999; Wayne et al., 2013). Literature has also established the negative association between WFC and the concerned two outcome variables. For example, Choi and Kim (2012) and Gözükara and Çolakoğlu (2016) show that WFC has a detrimental impact on job satisfaction; whereas Allen et al. (2000), Talukder et al. (2018) and Qureshi et al. (2019) suggest WFC is negatively associated with affective commitment. However, to our knowledge, the model proposed in Figure 1 has not been previously tested.

Second, it theorises a process by which the provision of managerial support for employees to manage their work and life roles accounts for an increase in affective commitment and job satisfaction among employees. We use leader-member exchange (LMX) theory (Deluga, 1994), which is underpinned by social exchange theory (Blau, 1964) and the norm of reciprocity (Gouldner, 1960). We postulate that supporting a subordinate employee in managing competing work-life demands (Eisenberger et al., 2002) helps decrease the level of WFC experienced by the employee (Anderson et al., 2002; Kim and Mullins, 2016; Lapierre and Allen, 2006; Mas-Machuca et al., 2016; Pluut et al., 2018; Talukder et al., 2018; Thompson et al., 1999). The employee will reciprocate with affective responses in terms of affective commitment and job satisfaction (Birtch et al., 2015; Major and Lauzun, 2010).

Third, our theoretical model was tested in the Australian context. WFC and related issues such as stress (Smith et al., 2002; Turner et al., 2014) have been considered as common among Australian employees (Skinner and Chapman, 2013). Despite reforms in childcare, parental leave and employment regulations over the past two decades, WFC continues to be a challenge in Australia. Many Australian employees were found to have encountered high

Figure 1.

Theoretical model

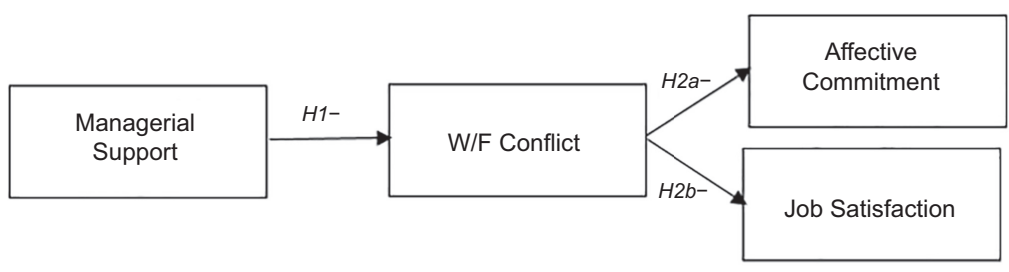


levels of WFC (Skinner and Pocock, 2014). WFC has received the attention from scholars, government, employers and employees (De Cieri et al., 2005; Zheng et al., 2016). Capturing the role of support from managers for employees to alleviate the conflict between work and family roles has the potential for organisations to understand the reciprocal exchange and in turn, to arrange necessary support in pursuit of desired employee attitudes and behaviour.
Work-family conflict and employee outcomes

\section{Theoretical foundation and hypotheses development}

In building the theoretical model (as displayed in Figure 1), we draw on the LMX theory to investigate the process through which WFC could be alleviated and lead to positive employee outcomes, including affective commitment and job satisfaction. The theory posits that LMX emerges from the social exchange between a manager and employee, wherein the negotiation of the employee's work role occurs through reciprocities between the two parties (Deluga, 1994; Major and Lauzun, 2010). Consistent with social exchange theory (Blau, 1964), the LMX theory advances the idea that reciprocity arises from the (perceived) fulfilment of needs and expectations by both parties in the relationship (Birtch et al., 2015). The LMX framework incorporates a focus on the quality of the manager-subordinate relationship (Gerstner and Day, 1997).

In addition, LMX and family-supportive managerial behaviour reportedly generate a positive environment in which both components influence and strengthen each other (Tummers and Bronkhorst, 2014). As noted by Graen and Scandura (1987, p. 182), it is crucial to the LMX quality that "each party must offer something the other party sees as valuable and each party must see the exchange as reasonably equitable or fair". Low-quality LMX relationships are characterised by transactional interactions, determined by the employment contract (Litano et al., 2016), in which employees receive standard benefits, including salary, superannuation and sick leave, in exchange for fulfilling formal job duties (Lapierre et al., 2006). By contrast, in high-quality LMX relationships, both instrumental and affective forms of support are increased (Bernas and Major, 2000) due to reciprocal exchanges between the manager and employee (Tummers and Bronkhorst, 2014).

The LMX theory suggests that when employees perceive that the manager is fulfilling his or her part of the LMX process through generating a family-friendly work environment and offering support for a range of work-related and life (personal) matters (Gözükara and ; Odriozola and Baraibar-Diez, 2018), reciprocity should emerge. On the basis of reciprocity, the exchange relationship between employees and managers (and the organisation) is formed (de Juana-Espinosa and Rakowska, 2018). This relationship is manifested in employees' inclination to demonstrate positive behaviours and attitudes towards the organisation (and manager) and job (Talukder et al., 2018), including affective commitment and job satisfaction (Birtch et al., 2015).

\section{Managerial support and WFC}

Research shows that high LMX is associated with lessened WFC. Using a sample of Dutch healthcare professionals, Tummers and Bronkhorst (2014) found that high LMX was negatively correlated with work-family interference, a construct that is closely related to WFC. Similar negative relationships have also been reported when examining the relationship between LMX and two types of WFC (Gutek et al., 1991), namely family interference with work and work interference with family. Lapierre et al. (2006), for instance, reported a negative relationship between LMX and family interference with work in their study of a Canadian non-profit organisation. Studies conducted by Bernas and Major (2000) and Major et al. (2008) have found a negative relationship between LMX and work interference with family.

A general consensus in the literature is that managerial support has beneficial effects on work-family experiences among employees (Litano et al., 2016). Scholars have contended that 
EJMBE 32,1

managerial support exerts a stronger influence on work-to-family conflict, as opposed to family-to-work conflict, since the source of support is work-related (Frone et al., 1992; Selvarajan et al., 2013). Karatepe and Kilic (2007) have lent empirical support to the relationship between managerial support and work-to-family conflict. This finding is consistent with that of Thomas and Ganster (1995). Similarly, results in a longitudinal study pertain to the relationship between work-to-family conflict and turnover intentions, which is most effectively buffered by support stemming from the work domain (Nohe and Sonntag, 2014).

Managers who display accommodating behaviours and compassion for employees' work and family responsibilities can have a significant impact on employees' endeavour to achieve work-life balance (Talukder et al., 2018; Thomas and Ganster, 1995). These managers serve as a source of instrumental and emotional assistance to buffer work-related demands (Choi, 2020). Support for work-life initiatives from managers propagates employees' perceptions of balance between their work and personal (life) commitments (Mas-Machuca et al., 2016). Indeed, managerial support is considered as a crucial workplace resource conducive to employees' achievement of better work-life balance (Greenhaus et al., 2012), including perceived decreased role conflict, specifically, decreased WFC (Talukder et al., 2018).

For instance, flexible working hours may optimise employees' ability to fulfil both work and non-work responsibilities (Russo et al., 2016). From a work-family perspective, Major and Lauzun (2010) suggest that not only does a manager appreciate an employee's contributions, the manager is also interested in ensuring that the employee feels appreciated and maintains productivity at work, including providing employees with assistance to handle work-family issues. Likewise, the employee could be inclined to contribute to the manager's goals and be confident in the manager's propensity for appropriate help and acknowledgement, namely aiding in the employee's ability to manage work-family demands. A meta-analysis suggests that support of immediate managers and positive work-family experience among employees are strongly related (Kossek et al., 2011). Empirical literature has also established that a supportive manager plays a pivotal role in reducing WFC (e.g. Allen, 2001; Behson, 2002; Thompson et al., 1999). Allen (2001) explains that managerial support exerts influence over employees' perceptions of their organisation's family-supportiveness, which could lead to reduced WFC. O'Driscoll et al. (2003) found that employees supervised by managers who provide more support for work-family balance reported less psychological strain than those with lower levels of managerial support. Managerial support is of great importance in workfamily balance (Greenhaus et al., 2012; Gözükara and Çolakoğlu, 2015), due to its alleviating effects on work-family tension (Beehr et al., 2000).

The work-to-family type of conflict reflects the extent to which participation in the family role is complicated as a result of participation in the work role (Greenhaus and Beutell, 1985). From this perspective, antecedents of WFC arise from the work domain, and the levels of work resources and work demands are associated with WFC (Byron, 2005; Michel et al., 2011). Therefore, the provision of managerial support for employees to participate in the family domain is likely to ameliorate the role demands at work interfering in family responsibilities (i.e. WFC). The present study therefore proposes the following hypothesis:

H1. Managerial support will be negatively associated with WFC.

\section{WFC and affective commitment, job satisfaction}

Affective commitment, as a component of organisational commitment (Meyer and Allen, 1991), is related to the role or roles of an individual within the social organisation, which could evoke satisfaction or stress experienced by the individual (Benligiray and Sönmez, 2012). Affective commitment is a form of psychological attachment originated from sense of pride and loyalty to an organisation or the manager as the organisation's representative (Allen and 
Meyer, 1990; Meyer et al., 2015), and is likely to be influenced by job- or role-related characteristics (i.e. job demands and resources) (Mowday et al., 1982).

Job satisfaction emanates from employees' favourable evaluations of the job (Locke, 1976). Detrimental job characteristics that cause incompatible requirements arising from one's work and family roles that potentially have restraining influences on role fulfilment (Greenhaus and Beutell, 1985) could be minimised by manager support or "psychologically and functionally useful resources" for employees to achieve work-life balance (Kossek et al., 2011, p. 294). Research has established that a common way in which employees reciprocate to their manager (and organisation) entails developing strong affective and socio-emotional attachment, including affective commitment and job satisfaction (Birtch et al., 2015; Gözükara and Çolakoğlu, 2015; Mukanzi and Senaji, 2017).

According to Thompson et al. (1999), family-supportive management with goodwill and intention to assist employees in balancing work-family responsibilities could evoke feelings of attachment from employees, including affective commitment and intention to leave. Similarly, a recent study conducted in the Australian financial sector revealed the significant role of managerial support in promoting work-life balance (i.e. decreased WFC), which subsequently affected employee attitudes, including job satisfaction, organisational commitment and life satisfaction (Talukder et al., 2018). Furthermore, substantial evidence suggests that affective commitment and job satisfaction are improved when an individual experiences fewer conflicts at the work-life interface. Meta-analytic evidence shows that WFC negatively impacts affective commitment and job satisfaction (Allen et al., 2000; Kossek and Ozeki, 1998). Results from a number of studies (e.g. Boles et al., 1997; Cannon, 1998; Good et al., 1988; Weale et al., 2019) reveal that WFC is related to a lower degree of job satisfaction and affective commitment. Drawing upon the LMX concepts and presented research evidence, it is proposed that:

H2a. WFC will be negatively associated with affective commitment.

$H 2 b$. WFC will be negatively associated with job satisfaction.

\section{The mediating role of $W F C$}

The above hypotheses combine to form a mediation model. In the present study, we applied the LMX framework, which is rooted in social exchange theory (Blau, 1964; Deluga, 1994), to theorise the process in which WFC will mediate the relationship between managerial support and employees' affective and socio-emotional outcomes, including affective commitment and job satisfaction. We predict that it is likely that managerial support will lessen the level of conflicts between employees' work and life roles (Hypothesis1), which in turn will promote affective commitment (Hypothesis 2a) and job satisfaction (Hypothesis 2b). Therefore:

$H 3 a$. WFC will mediate the relationship between managerial support and affective commitment.

$H 3 b$. WFC will mediate the relationship between managerial support and job satisfaction.

\section{Methods}

The study used a cross-sectional design, and data were collected through a survey of employees from an Australian manufacturing organisation.

\section{Sample and data collection}

The sampling frame comprised all employees of an Australian manufacturing organisation. Initially multiple organisations were approached, however only one organisation agreed to
Work-family conflict and employee outcomes 
EJMBE 32,1

participate and provided access to its employees. An e-survey link was sent to each employee via the HR manager. The responses were directly received by the researchers, with no involvement of the HR manager. Employees' self-reported data were collected as opposed to peer or supervisor ratings, objective observations or archival data. The data were collected between July 2013 to September 2013. A total of 250 employees were sent a survey. After deleting incomplete responses, 134 surveys with all questions answered led to a response rate of $53.6 \%$. Final sample size was within the acceptable range of 30-500 responses, defined by scholarly standards (Roscoe, 1975). It also fulfils the various rules of thumb, such as $50+k$ (Harris, 1975), $5 k$ (Tabachnick and Fidell, 1989), $50+8 k$ (Green, 1991) and 100 (Combs, 2010). The value of $k$ for the current study is 4 . The respondents comprised $75 \%$ male and $25 \%$ female, with a mean age of 45 years. Of participating employees, $62.5 \%$ were below the age of 45, and $47.8 \%$ had the European/Anglo-American background.

\section{Measures}

This study uses four latent variables measured through multiple indicators which represent the underlying constructs (Byrne, 1998). These indicators are repeatedly used in the literature for the measurement of these latent constructs that cannot be directly measured (e.g. Bergami and Bagozzi, 2000; Boyar et al., 2005). This is referred as parcelling in literature that involves "averaging or summing several raw items to form a single score, which can then be used as an indicator of a latent variable" (Sterba, 2011, p. 554). Hence, the main four variables (see Figure 1) are based on reflective scales where the measured items "jointly influence the latent construct, and meaning emanates from the measures to the construct in the sense that the full meaning of the composite latent construct is derived from its measures" (MacKenzie et al., 2005 , p. 713). The responses to the items were averaged to create the final score for the construct (e.g. Armstrong et al., 2010; Liao et al., 2009), as these indicators reflect the heterogeneous causes of latent construct (Jarvis et al., 2003). Empirical justifications for averaging items include attaining normality, enhancing reliability and achieving a better model fit (Bandalos and Finney, 2001). Summing items can lead to misleading values in the presence of missing responses to some items.

Predictors. Work-family related managerial support was measured by an eleven-item scale developed by Thompson et al. (1999), with a reported reliability of 0.91 . The exploratory factor analysis was run to check the validity of the scale with the current data. Three items were dropped from the scale due to factor loadings below 0.4. A sample item is "In general, managers are quite accommodating of family-related needs". The Cronbach's alpha value for the current study is 0.875 . Scales were reported on a five-point Likert scale from " 1 " representing "strongly disagree" to " 5 " representing "strongly agree".

Outcomes. A seven-item scale was used to measure job satisfaction, developed by King et al. (2012), asking the degree of employee satisfaction with respect to different aspects of the job, for example "support from immediate manager" and "value of work". The reported reliability of the scale was 0.86 . The Cronbach's alpha value for the current study is 0.89 . Affective commitment was measured using a four-item scale originally developed by Allen and Meyer (1990). The sample item is "Working at this organisation has a great deal of personal meaning to me". The scale measures the emotional attachment, identification and involvement of employees with the organisation. The Cronbach's alpha value for the current study is 0.84 . For both scales, employees reported on a five-point Likert scale from "very dissatisfied" to "very satisfied".

Mediator. The mediating variable of $W F C$ was measured with a scale used by Netemeyer et al. (1996), with a reported reliability of 0.88 . The scale comprised five items, for example, "The demands of my work interfere with my home and family life". Employees reported on five response choices ranging from "strongly disagree" to "strongly agree". The Cronbach's alpha for the current study is 0.94 . 
Controls. The analysis controlled for the effects of gender and age. Participant gender was coded as a dummy variable, where " 0 " = male and " 1 " = female. Age was an open-ended question in the survey. To convert it into a categorical variable, we calculated the median value of age and created two categories above and below the median value. Lower values were represented by " 0 ", while the upper values were represented by " 1 ". A total of $51.5 \%$ of the values lay below the median value.

\section{Results}

Means, correlations and standard deviations for all variables in the theoretical model are presented in Table 1. The data were checked for multivariate assumptions through Cook's distance, skewness, kurtosis and collinearity diagnostics. All the values were below 0.1 for Cook's distance hence showing no outliers (Cook, 1977). Similar was the case for skewness, kurtosis and variation inflation factor (VIF) values. The Mardia's standardised coefficient value is a multivariate measure of normality. Its value equal to or less than 1.96 indicates multivariate normality of the data (e.g. Vargas-Halabí et al., 2017). For the proposed model, the value is 1.711 indicating the normality of data. Fornell-Larcker (1981) criterion has been used to establish the convergent and discriminant validity of the constructs. According to the criterion, the convergent validity can be assessed through average variance extracted (AVE), with the values above 0.5 acceptable. For the current model the AVE values for all the construct are above 0.5 , indicating the presence of convergent validity of the constructs (see Table 2). On the other hand, the criterion proposes the presence of discriminant validity if the square root of AVE for each construct is greater than the correlations involving the constructs. The results fulfil the criterion for the presence of discriminant validity in the current data. At the same time the correlation coefficient values for all variables were below 0.5 , indicating convergent and discriminant validity of the data. Convergent and discriminant validity of variables were also established through exploratory and confirmatory factor analysis, where all factor loadings were above 0.5 (see Table 2: Cunningham et al., 2001;

\begin{tabular}{|c|c|c|c|c|c|c|c|}
\hline VARIABLE & MEAN & $\mathrm{SD}$ & 1 & 2 & 3 & 4 & 5 \\
\hline $\begin{array}{l}\text { Predictors } \\
\text { 1. Managerial support }\end{array}$ & 3.60 & 0.575 & & & & & \\
\hline $\begin{array}{l}\text { Mediator } \\
\text { 2. Work-family conflict }\end{array}$ & 2.69 & 0.969 & $-0.177^{*}$ & & & & \\
\hline $\begin{array}{l}\text { Outcome } \\
\text { 3. Affective commitment } \\
\text { 4. Job satisfaction }\end{array}$ & $\begin{array}{l}3.43 \\
3.81\end{array}$ & $\begin{array}{l}0.710 \\
0.640\end{array}$ & $\begin{array}{l}0.477^{* *} \\
0.110\end{array}$ & $\begin{array}{l}-0.206^{*} \\
-0.345^{* *}\end{array}$ & $0.254^{* *}$ & & \\
\hline $\begin{array}{l}\text { Controls } \\
\text { 5. Gender } \\
6 . \text { Age }\end{array}$ & $\begin{array}{l}0.27 \\
1.49\end{array}$ & $\begin{array}{l}0.445 \\
0.502\end{array}$ & $\begin{aligned} & 0.069 \\
- & 0.179^{*}\end{aligned}$ & $\begin{array}{r}-0.026 \\
0.017\end{array}$ & $\begin{array}{l}0.201^{*} \\
0.039\end{array}$ & $\begin{array}{l}-0.076 \\
-0.016\end{array}$ & $-0.182^{*}$ \\
\hline
\end{tabular}

Work-family conflict and employee outcomes

Note(s): $* p<0.05$ (2-tailed). $* * p<0.01$ (2-tailed)

\begin{tabular}{lccr}
\hline Variable & Reliability & Convergent validity & \\
\cline { 1 - 2 } Managerial support & 0.87 & 0.50 & Table 2. \\
Work-family conflict & 0.94 & 0.74 & Construct reliability \\
Affective commitment & 0.84 & 0.51 & and validity \\
Job satisfaction & 0.89 & 0.56 & \\
\hline
\end{tabular}


EJMBE 32,1

80

Tharenou et al., 2007). The cross-sectional nature of data may also pose threats of common method bias (Podsakoff et al., 2003). Consistent with past literature, the statistical procedures were used to reduce the bias (e.g. Bitrian et al., 2020; Erkutlu and Chafra, 2019). Therefore, Harmon's single factor test was conducted to exclude superfluous items. The results indicate that $35.15 \%$ of total variance was explained by single factor, demonstrating no risk of common method bias.

The structural equation modelling (SEM) technique in Analysis of Moment Structures (AMOS) was used to test the hypothesised model shown in Figure 1. Hypotheses 1, 2a and 2b state the direct relationships in the model. Hypothesis 1 proposes that work-family related managerial support is negatively associated with WFC $(\beta=-0.40, \alpha<0.05)$. Hypotheses $2 \mathrm{a}$ and $2 \mathrm{~b}$ anticipate that WFC is negatively related to affective commitment $(\beta=-0.51$, $\alpha<0.001)$ and job satisfaction $(\beta=-0.42, \alpha<0.001)$, respectively. Table 3 presents the estimates and significance of the direct effects in the model. The $95 \%$ confidence interval using 5000 bias corrected samples does not include zero, reporting the relationships to be significant.

Hypothesis 3a states that WFC will mediate the relationship between managerial support and affective commitment $(\beta=0.32$, LLCI $=0.007$, ULCI $=0.140, \alpha<0.05)$, whereas hypothesis $3 \mathrm{~b}$ predicts the mediating influence of $\mathrm{WFC}$ on the relationship of managerial support and job satisfaction $(\beta=0.30, \mathrm{LLCI}=0.010$, ULCI $=0.167, \alpha<0.05)$. The results (presented in Table 4) indicate that managerial support had a positively significant effect on affective commitment and job satisfaction via WFC. The 95\% confidence interval using 5000 bias corrected samples does not include zero, reporting the relationships to be significant.

The chi-square to the degrees of freedom ratio for the complete model is 1.627, suggesting that the model is fit for the data. The root mean square error of approximation (RMSEA) is the most used index to check model fitness (McDonald and Ho, 2002). For the proposed model, the RMSEA value is 0.05, indicating a model fit (Schumacker and Lomax, 2004; Steiger, 2007). Other absolute fit value measures are the goodness of fit index (GFI) and adjusted goodness of fit index (AGFI). For the proposed model, the GFI and AGFI values are 0.977 and 0.919, respectively, showing acceptable variance for the study (Hooper et al., 2008). The incremental fit indices mostly reported for SEM are the comparative fit index (CFI), normed fit index (NFI) and Tucker Lewis index (TLI). The CFI, NFI and TLI values for the proposed model are 0.954,

\begin{tabular}{llll}
\hline Predictor & Outcome & Estimate & LLCI - ULCI \\
\hline Managerial support & Work-family conflict & $-0.40^{* * *}$ & $-0.622--0.036$ \\
Work-family conflict & Affective commitment & $-0.51^{* * *}$ & $-0.267--0.092$ \\
Work-family conflict & Job satisfaction & $-0.42^{* * *}$ & $-0.330--0.116$
\end{tabular}

Table 3.

Direct effects

Note(s): $* * * p<0.001, * * p<0.05$

Bootstrap sample size $=5000$ bias corrected, $\mathrm{LL}=$ lower limit, $\mathrm{UL}=$ upper limit, $\mathrm{CI}=$ Confidence Interval, Level of confidence $=95 \%$

Table 4.

Mediating effects

\begin{tabular}{lllcr}
\hline Predictor & Mediator & Outcome & Estimate & LLCI - ULCI \\
\hline Managerial support & Work-family conflict & Affective commitment & $0.32^{* *}$ & $0.007-0.140$ \\
Managerial support & Work-family conflict & Job satisfaction & $0.30^{* *}$ & $0.010-0.167$
\end{tabular}

Note(s): $* * p<0.05$

Bootstrap sample size $=5000$ bias corrected, $\mathrm{LL}=$ lower limit, $\mathrm{UL}=$ upper limit, $\mathrm{CI}=$ Confidence Interval, Level of confidence $=95 \%$ 
0.90 and 0.886, respectively. According to Schumacker and Lomax (2004), values approaching one are treated as good and acceptable. All the parsimonious, absolute and incremental fit indices show the proposed model fit for the study.

\section{Discussion}

The basic purpose of this paper was to explore whether: (1) managerial support decreases WFC, (2) WFC is negatively associated with affective commitment and job satisfaction, and (3) WFC mediates the relationship between managerial support and outcomes (affective commitment and job satisfaction). The results reveal all the proposed relationships are significant.

The results indicate a negative relationship between work-family related managerial support and WFC. Our findings support and strengthen the literature suggesting decrease in WFC because of managerial support (e.g. Allen, 2001; Drummond et al., 2017; Frone et al., 1992; Karatepe and Kilic, 2007; Pluut et al., 2018; Selvarajan et al., 2013; Thomas and Ganster, 1995). For example, Pluut et al. (2018) stated that supervisor's support mitigates the withinindividual workload effects on emotional exhaustion which reduces WFC. Kossek et al. (2011) reported a strong relationship between immediate manager support and work-family experience. Managerial support is also found to exert influence on employees' perceptions of an organisation's family supportiveness, which can lead to lower WFC (Allen, 2001). Similarly, Drummond et al. (2017) and Lapierre et al. (2008) found negative association between supervisory support and WFC.

Furthermore, the negative association between WFC and affective commitment/job satisfaction found in this study is widely supported in the literature (e.g. Allen et al., 2000; Boles et al., 1997; Cannon, 1998; Good et al., 1988; Gözükara and Çolakoğlu, 2016; Kossek and Ozeki, 1998; McDowell et al., 2019; Qureshi et al., 2019). For example, Weale et al. (2019) found a significant association between WFC and job satisfaction among residential aged care employees. Choi and Kim (2012) and Grandey et al. (2005) reported an increase in job satisfaction with the decrease in WFC. Regarding commitment, Qureshi et al. (2019) reported a significant negative relationship between WFC and affective commitment. Lyness and Thompson (1997) also found negative association between WFC and affective commitment. Meta-analytic evidence has also attributed WFC to a broad range of employee outcomes, such as job dissatisfaction, low organisational commitment and high turnover intention (Allen et al., 2000; Eby et al., 2005; Mesmer-Magnus and Viswesvaran, 2005). Therefore, the findings of the current study strengthen the evidence for negative effects of WFC on job satisfaction and effective commitment.

Our findings indicate that the mediating relationships of managerial support-WFCoutcomes are also significant. This study provides pioneering evidence of the mediating role of WFC in the relationship between managerial support and affective commitment. However, the mediating relationship of managerial support-WFC-job satisfaction has been previously studied by Anderson et al. (2002) and Hwang and Ramadoss (2017). They reported significant mediation of WFC in the relationship of managerial support and job satisfaction. There is adequate theoretical support for the results via LMX theory. The LMX theory suggests that managers' fulfilment of needs and expectations lead employees to reciprocate the same behaviour towards their managers and the organisation (Birtch et al., 2015; Gözükara and Çolakoğlu, 2015; Odriozola and Baraibar-Diez, 2018). The quality of this exchange relationship holds much importance (Gerstner and Day, 1997; Solís, 2017).

\section{Theoretical and research contributions}

This study makes various theoretical and research contributions. First, the findings provide support for LMX theory (Deluga, 1994), that is based on social exchange theory and its norm
Work-family conflict and employee outcomes 
EJMBE 32,1 of reciprocity (Blau, 1964; Gouldner, 1960). The fulfilment of needs and expectations of managers and employees through positive social exchange (de Juana-Espinosa and Rakowska, 2018) underpins the philosophy of LMX theory (Birtch et al., 2015; Deluga, 1994; Major and Lauzun, 2010). Therefore, the decrease in the level of WFC experienced by employees, due to managers caring for employee well-being and family-supportive behaviour, led employee to reciprocate positively in the form of enhance affective commitment and job satisfaction (Birtch et al., 2015; Eisenberger et al., 2002). Second, the findings provide empirical evidence for the negative linear relationship between managerial support and WFC, and WFC and affective commitment/job satisfaction. This strengthens the argument that demonstration of family-supportive behaviours from managers helps employees to manage work-life demands effectively, reducing WFC (Drummond et al., 2017; Eisenberger et al., 2002; Pluut et al., 2018) and leading to affective responses from employees in terms of commitment and job satisfaction (Birtch et al., 2015; Qureshi et al., 2019). This study focuses on managerial support as it has been considered as most useful and valuable for employees ( $\mathrm{Ng}$ and Sorensen, 2008).

Third, this study addresses a gap in the literature by reporting the direct and mediating relationships in the Australian context that have not previously been explored. Researchers can also further explore the proposed framework in different cultural settings with larger data sets and longitudinal analyses. The influence and type of managerial support and facets of WFC might differ in developed, developing and under-developing cultures. Our research used the limited number of variables to undertake the focused study rather than the comprehensive study; however, WFC also has a number of other predictors that need to be further investigated, like work-family culture, work-role ambiguity, co-worker support, task autonomy, schedule flexibility and so on (Michel et al., 2011; Thompson et al., 1999). Similarly, managerial support and WFC can influence employee behaviours and outcomes at a larger level. Analysing larger sets of predictors and outcomes of WFC can help understand the reasons for the increase/decrease in WFC.

Fourth, the study provides pioneering evidence for the significant mediating effect of WFC on the relationship of managerial support and outcomes (affective commitment and job satisfaction). Studies can also be undertaken to compare the level of managerial support and family support in enhancing or reducing WFC (Madhavi, 2015; Michel et al., 2011). At the same time, employee personality traits can also play a vital role in defining WFC (Michel et al., 2011).

\section{Practical implications}

Managerial support has been considered as the most important and valuable resource for employees to reduce WFC (Kossek et al., 2011; Ng and Sorensen, 2008). According to a survey by the Melbourne Institute: Applied Economic and Social Research, employees facing WFC can face problems in their work performance, their children's functioning and their family life (Wilkins et al., 2019). WFC and stress in lives have been considered as common among Australian workers (Skinner and Chapman, 2013). The supportive and accommodating work-family climate among managers and employees can help employees achieve a balance (Talukder et al., 2018; Thomas and Ganster, 1995) as they find instrumental and emotional assistance to fulfil work-related demands (Choi, 2020). Increasing attention of organisations' impact on the manager-employee relationship requires firms to focus on the quality of this exchange relationship. Therefore, evaluating the pros and cons of this relationship holds significant practical implications. The proposed theoretical framework helps organisations to understand this reciprocal relationship and its consequences. The more positive managerial support employees receive, the more positive their behaviours will be towards the organisation due to decreased conflict in their work and family lives. The improved 
relationships among managers and employees will ultimately result in better outcomes for both employees and the organisation.

The HILDA Survey (Wilkins et al., 2019) states that $12 \%$ of employees facing high WFC for around five years will certainly leave employment. This shows that if organisations understand the reasons for WFC and successfully create a family-supportive environment, they can develop a positive exchange relationship between managers and employees, leading to more positive outcomes. This study draws attention to the importance of managerial support in reducing WFC as managerial support plays a critical role in mitigating WFC (Goh et al., 2015). Managers' family-supportive behaviour towards employees will eventually force employees to reciprocate positive behaviours and attitudes towards the organisation (Bettencourt and Brown, 1997; Hicks-Clarke and Iles, 2000; Mor Barak and Levin, 2002). Organisations can invest in training their managers to maximise their family-supportive behaviours (Hammer et al., 2011; Mukanzi and Senaji, 2017); this will help managers to use resources to enhance employee well-being and alleviate the negative effects of a high workload.

According to a media release in 2019 by Australian Institute of Family Studies (AIFS, 2019) vis Australian Government, the incompatible work and family demands are a source of threat to the mental health of mothers as well as fathers. Fathers experiencing high WFC have reported to be psychologically distressed, and thus reduction in WFC can significantly improve their mental health (Cooklin, 2018). Therefore, it is important for organisations to boost managers' training to support employee health and well-being to reap benefits of the most critical resource of the organisation and to make it their competitive edge. Such training will aid them to communicate effectively with their workers and develop compatible working roles to enhance positive employee outcomes like affective commitment and job satisfaction (Deluga, 1994; Major and Lauzun, 2010). These positive outcomes will ultimately enhance organisational productivity.

\section{Limitations}

This study holds certain limitations. First, only managerial support is considered as the predictor of WFC, whereas many other organisational and family factors can influence WFC. Future research can account for additional predictors of WFC, such as work/family behaviour support, family non-supportive culture and work/family culture (Glaveli et al., 2013; Thompson et al., 1999). Second, this study was conducted in the Australian contextthe influence and support of managers may differ in other cultural settings. Third, the limited sample size and inclusion of only one manufacturing organisation may limit the generalisability of the findings. Fourth, the study uses a cross-sectional, single-source, selfreported data design. This can constitute a risk of common method variance and does not allow for causal inferences. Future research can expand the scope of the study by using a longitudinal design to assess the relationships.

\section{References}

AIFS (2019), Conflict Between Work and Family Affects Fathers' and Childrens' Mental Health, Australian Government: Australian Institute of Family Studies, available at: https://aifs.gov.au/ media-releases/conflict-between-work-and-family-affects-fathers-and-childrens-mental-health.

Allen, T. (2001), "Family-supportive work environments: the role of organizational perceptions", Journal of Vocational Behavior, Vol. 58 No. 3, pp. 414-435.

Allen, N.J. and Meyer, J.P. (1990), "The measurement and antecedents of affective, continuance and normative commitment to the organization”, Journal of Occupational Psychology, Vol. 63 No. 1, pp. 1-18. 
EJMBE 32,1

\section{4}

Allen, T., Herst, D., Bruck, C. and Sutton, M. (2000), "Consequences associated with work-to-family conflict: a review and agenda for future research", Journal of Occupational Health Psychology, Vol. 5 No. 2, pp. 278-308.

Anderson, S., Coffey, B. and Byerly, R. (2002), "Formal organizational initiatives and informal workplace practices: links to work-family conflict and job-related outcomes", Journal of Management, Vol. 28 No. 6, pp. 787-810.

Armstrong, C., Flood, P.C., Guthrie, J.P., Liu, W., MacCurtain, S. and Mkamwa, T. (2010), "The impact of diversity and equality management on firm performance: beyond high performance work systems", Human Resource Management, Vol. 49 No. 6, pp. 977-998.

Babin, B. and Boles, J. (1996), "The effects of perceived co-worker involvement and supervisor support on service provider role stress, performance and job satisfaction”, Journal of Retailing, Vol. 72 No. 1, pp. 57-75.

Bandalos, D.L. and Finney, S.J. (2001), "Item parceling issues in structural equation modelling”, in Marcoulides, G.A. and Schumacker, R.E. (Eds), New Developments and Techniques in Structural Equation, Erlbaum, Mahwah, NJ, pp. 269-296.

Beehr, T., Jex, S., Stacy, B. and Murray, M. (2000), "Work stressors and coworker support as predictors of individual strain and job performance", Journal of Organizational Behavior, Vol. 21 No. 4, pp. 391-405.

Behson, S. (2002), "Which dominates? The relative importance of work-family organizational support and general organizational context on employee outcomes", Journal of Vocational Behavior, Vol. 61 No. 1, pp. 53-72.

Benligiray, S. and Sönmez, H. (2012), "Analysis of organizational commitment and work-family conflict in view of doctors and nurses", The International Journal of Human Resource Management, Vol. 23 No. 18, pp. 3890-3905.

Bergami, M. and Bagozzi, R.P. (2000), "Self-categorization, affective commitment and group selfesteem as distinct aspects of social identity in the organization", British Journal of Social Psychology, Vol. 39 No. 4, pp. 555-577.

Bernas, K. and Major, D. (2000), "Contributors to stress resistance: testing a model of women's workfamily conflict", Psychology of Women Quarterly, Vol. 24 No. 2, pp. 170-178.

Bettencourt, L. and Brown, S. (1997), "Contact employees: relationships among workplace fairness, job satisfaction and prosocial service behaviors", Journal of Retailing, Vol. 73, pp. 39-61.

Birtch, T., Chiang, F. and Van Esch, E. (2015), "A social exchange theory framework for understanding the job characteristics-job outcomes relationship: the mediating role of psychological contract fulfillment", The International Journal of Human Resource Management, Vol. 27 No. 11, pp. 1-20.

Bitrián, P., Buil, I. and Catalán, S. (2020), 'Gamification in sport apps: the determinants of users' motivation”, European Journal of Management and Business Economics, Vol. 29 No. 3, pp. 365-381.

Blau, P. (1964), Exchange and Power in Social Life, John Wiley, New York, NY.

Boles, J., Johnston, M. and Hair, J. (1997), "Role stress, work-family conflict and emotional exhaustion: inter-relationships and effects on some work-related consequences", Journal of Personal Selling and Sales Management, Vol. 17 No. 1, pp. 17-28.

Boyar, S.L., Maertz, C.P. Jr and Pearson, A.W. (2005), "The effects of work-family conflict and familywork conflict on nonattendance behaviors", Journal of business Research, Vol. 58 No. 7, pp. 919-925.

Byrne, B.M. (1998), "Structural equation modeling with LISREL, PRELIS, and SIMPLIS: basic concepts", Applications and Programming, pp. 3-40.

Byron, K. (2005), "A meta-analytic review of work-family conflict and its antecedents", Journal of Vocational Behavior, Vol. 67 No. 2, pp. 169-198.

Cannon, D. (1998), "Better understanding the impact of work interferences on organizational commitment”, Marriage and Family Review, Vol. 28 Nos 1-2, pp. 153-166. 
Chambel, M., Carvalho, V., Cesario, F. and Lopes, S. (2017), "The work-to-life conflict mediation between job characteristics and well-being at work part-time vs full-time employees", Career Development International, Vol. 22 No. 2, pp. 142-164.

Charoensukmongkol, P., Moqbel, M. and Gutierrez-Wirsching, S. (2016), "The role of co-worker and supervisor support on job burnout and job satisfaction", Journal of Advances in Management Research, Vol. 13 No. 1, pp. 4-22.

Choi, Y. (2020), "A study of the influence of workplace ostracism on employees' performance: moderating effect of perceived organizational support", European Journal of Management and Business Economics, Vol. 29 No. 3, pp. 333-345.

Choi, J.H. and Kim, T.Y. (2012), "Work-family conflict, work-family facilitation, and job outcomes in the Korean hotel industry", International Journal of Contemporary Hospitality Management, Vol. 24 No. 7, pp. 1011-1028.

Cloninger, P. and Selvarajan, T. (2015), "The mediating influence of work-family conflict and the moderating influence of gender on employee outcomes", The International Journal of Human Resource Management, Vol. 26 No. 18, pp. 2269-2287.

Combs, J.G. (2010), "Big samples and small effects: let's not trade relevance and rigor for power", Academy of Management Journal, Vol. 53, pp. 9-13.

Cook, R.D. (1977), "Detection of influential observation in linear regression", Technometrics, Vol. 19 No. 1, pp. 15-18.

Cooklin, A. (2018), “Conflicts between work and family and fathers' mental health”, The 15th Biennial AIFS Conference, Australian Government: Australian Institute of Family Studies, Melbourne, pp. 1-3, available at: https://aifs.gov.au/aifs-conference.

Cunningham, W.A., Preacher, K.J. and Banaji, M.R. (2001), "Implicit attitude measures: consistency, stability, and convergent validity", Psychological Science, Vol. 12 No. 2, pp. 163-170.

De Cieri, H., Holmes, B., Abbott, J. and Pettit, T. (2005), “Achievements and challenges for work/life balance strategies in Australian organizations", The International Journal of Human Resource Management, Vol. 16 No. 1, pp. 90-103.

de Juana-Espinosa, S. and Rakowska, A. (2018), "Public sector motivational practices and their effect on job satisfaction: country differences", European Journal of Management and Business Economics, Vol. 27 No. 2, pp. 141-154.

Deluga, R. (1994), "Supervisor trust building, leader-member exchange and organizational citizenship behaviour", Journal of Occupational and Organizational Psychology, Vol. 67, p. 315.

Drummond, S., O’Driscoll, M.P., Brough, P., Kalliath, T., Siu, O.L., Timms, C., Riley, D., Sit, C. and Lo, D. (2017), "The relationship of social support with well-being outcomes via work-family conflict: moderating effects of gender, dependants and nationality”, Human Relations, Vol. 70 No. 5, pp. 544-565.

Eby, L., Casper, W., Lockwood, A., Bordeaux, C. and Brinley, A. (2005), "Work and family research in IO/OB: content analysis and review of the literature (1980-2002)", Journal of Vocational Behavior, Vol. 66 No. 1, pp. 124-197.

Eisenberger, R., Stinglhamber, F., Vandenberghe, C., Sucharski, I. and Rhoades, L. (2002), "Perceived supervisor support: contributions to perceived organizational support and employee retention", Journal of Applied Psychology, Vol. 87 No. 3, pp. 565-573.

Erkutlu, H. and Chafra, J. (2019), "Leader Machiavellianism and follower silence: the mediating role of relational identification and the moderating role of psychological distance", European Journal of Management and Business Economics, Vol. 28 No. 3, pp. 323-342.

Ford, M., Heinen, B. and Langkamer, K. (2007), "Work and family satisfaction and conflict: a metaanalysis of cross-domain relations", The Journal of Applied Psychology, Vol. 92 No. 1, pp. 57-80.

Fornell, C. and Larcker, D.F. (1981), "Structural equation models with unobservable variables and measurement error: algebra and statistics", Journal of Marketing Research, Vol. 18 No. 3, pp. 382-388. 
EJMBE 32,1

Frone, M., Russell, M. and Cooper, M. (1992), "Antecedents and outcomes of work-family conflict: testing a model of the work-family interface", Journal of Applied Psychology, Vol. 77 No. 1, pp. 65-78.

Galletta, M., Portoghese, I., Melis, P., Aviles Gonzalez, C., Finco, G., Contu, P. and Campagna, M. (2019), "The role of collective affective commitment in the relationship between work-family conflict and emotional exhaustion among nurses: a multilevel modeling approach", BMC Nursing, Vol. 18 No. 1, p. 5.

Gerstner, C. and Day, D. (1997), "Meta-analytic review of leader-member exchange theory: correlates and construct issues", Journal of Applied Psychology, Vol. 82 No. 6, pp. 827-844.

Glaveli, N., Karassavidou, E. and Zafiropoulos, K. (2013), "Relationships among three facets of familysupportive work environments, work-family conflict and job satisfaction: a research in Greece", The International Journal of Human Resource Management, Vol. 24 No. 20, pp. 3757-3771.

Gözükara, İ. and Çolakoğlu, N. (2015), "The impact of manager support and work family conflict on job satisfaction”, Business Management Dynamics, Vol. 5 No. 6, pp. 13-25.

Gözükara, İ. and Çolakoğlu, N. (2016), "The mediating effect of work family conflict on the relationship between job autonomy and job satisfaction”, Procedia, Social and Behavioral Sciences, No. 229, pp. 253-266.

Goh, Z., Ilies, R. and Wilson, K.S. (2015), "Supportive supervisors improve employees' daily lives: the role supervisors play in the impact of daily workload on life satisfaction via work-family conflict", Journal of Vocational Behavior, Vol. 89, pp. 65-73.

Good, L., Sisler, G. and Gentry, J. (1988), "Antecedents of turnover intentions among retail management", Journal of Retailing, Vol. 64 No. 3, p. 295.

Gouldner, A. (1960), "The norm of reciprocity: a preliminary statement”, American Sociological Review, Vol. 25 No. 2, pp. 161-178.

Graen, G.B. and Scandura, T.A. (1987), "Toward a psychology of dyadic organizing”, Research in Organizational Behavior, Vol. 9, pp. 175-208.

Grandey, A., Cordeiro, B. and Crouter, A. (2005), "A longitudinal and multi-source test of the workfamily conflict and job satisfaction relationship", Journal of Occupational and Organizational Psychology, Vol. 78 No. 3, pp. 305-323.

Green, S.B. (1991), "How many subjects does it take to do a regression analysis?", Multivariate Behavioral Research, Vol. 26, pp. 499-510.

Greenhaus, J. and Beutell, N. (1985), "Sources of conflict between work and family roles", The Academy of Management Review, Vol. 10 No. 1, pp. 76-88.

Greenhaus, J., Ziegert, J. and Allen, T. (2012), "When family-supportive supervision matters: relations between multiple sources of support and work-family balance", Journal of Vocational Behavior, Vol. 80 No. 2, pp. 266-275.

Gutek, B.A., Searle, S. and Klepa, L. (1991), "Rational versus gender role explanations for work-family conflict", Journal of Applied Psychology, Vol. 76 No. 4, p. 560.

Hammer, L.B., Kossek, E.E., Anger, W.K., Bodner, T. and Zimmerman, K.L. (2011), "Clarifying workfamily intervention processes: the roles of work-family conflict and family-supportive supervisor behaviors", Journal of Applied Psychology, Vol. 96 No. 1, p. 134.

Harris, R.J. (1975), A Primer of Multivariate Statistics, Academic Press, New York, NY.

Hicks-Clarke, D. and Iles, P. (2000), "Climate for diversity and its effects on career and organisational attitudes and perceptions", Personnel Review, Vol. 29, pp. 324-345.

Hooper, D., Coughlan, J. and Mullen, M. (2008), "Structural equation modelling: guidelines for determining model fit", Electronic Journal of Business Research Methods, Vol. 6, pp. 53-60.

Hwang, W. and Ramadoss, K. (2017), "The job demands-control-support model and job satisfaction across gender: the mediating role of work-family conflict", Journal of Family Issues, Vol. 38 No. 1, pp. 52-72. 
Jarvis, C.B., MacKenzie, S.B. and Podsakoff, P.M. (2003), "A critical review of construct indicators and measurement model misspecification in marketing and consumer research", Journal of Consumer Research, Vol. 30 No. 2, pp. 199-218.

Karatepe, O. and Karadas, G. (2016), 'Service employees' fit, work-family conflict, and work engagement", Journal of Services Marketing, Vol. 30 No. 5, pp. 554-566.

Karatepe, O. and Kilic, H. (2007), "Relationships of supervisor support and conflicts in the workfamily interface with the selected job outcomes of frontline employees", Tourism Management, Vol. 28 No. 1, pp. 238-252.

Kim, T. and Mullins, L.B. (2016), "How does supervisor support and diversity management affect employee participation in work/family policies?”, Review of Public Personnel Administration, Vol. 36 No. 1, pp. 80-105.

King, E.B., Dawson, J.F., Kravitz, D.A. and Gulick, L.M.V. (2012), "A multilevel study of the relationships between diversity training, ethnic discrimination and satisfaction in organizations", Journal of Organizational Behavior, Vol. 33 No. 1, pp. 5-20.

Kinman, G., Clements, A.J. and Hart, J. (2017), "Working conditions, work-life conflict, and well-being in U.K. Prison officers: the role of affective rumination and detachment", Criminal Justice and Behavior, Vol. 44 No. 2, pp. 226-239.

Kossek, E.E. and Ozeki, C. (1998), "Work-family conflict, policies, and the job-life satisfaction relationship: a review and directions for organizational behavior-human resources research", Journal of Applied Psychology, Vol. 83 No. 2, pp. 139-149.

Kossek, E.E. and Ozeki, C. (1999), "Bridging the work-family policy and productivity gap: a literature review", Community, Work and Family, Vol. 2 No. 1, pp. 7-32.

Kossek, E., Pichler, S., Bodner, T. and Hammer, L. (2011), "Workplace social support and work-family conflict: a meta-analysis clarifying the influence of general and work-family-specific supervisor and organizational support”, Personnel Psychology, Vol. 64 No. 2, pp. 289-313.

Lambert, E.G., Qureshi, H., Keena, L.D., Frank, J. and Hogan, N.L. (2019), "Exploring the link between work-family conflict and job burnout among Indian police officers", Police Journal (Chichester), Vol. 92 No. 1, pp. 35-55.

Lapierre, L. and Allen, D. (2006), "Work-supportive family, family-supportive supervision, use of organizational benefits, and problem-focused coping: implications for work-family conflict and employee well-being", Journal of Occupational Health Psychology, Vol. 11 No. 2, pp. 169-181.

Lapierre, L., Hackett, R. and Taggar, S. (2006), "A test of the links between family interference with work, job enrichment and leader-member exchange", Applied Psychology, Vol. 55 No. 4, pp. 489-511.

Lapierre, L., Spector, P.E., Allen, T.D., Poelmans, S., Cooper, C.L., O'driscoll, M.P., Sanchez, J.I., Brough, P. and Kinnunen, U. (2008), "Family-supportive organization perceptions, multiple dimensions of work-family conflict, and employee satisfaction: a test of model across five samples", Journal of Vocational Behavior, Vol. 73 No. 1, pp. 92-106.

Liao, H., Toya, K., Lepak, D.P. and Hong, Y. (2009), "Do they see eye to eye? Management and employee perspectives of high-performance work systems and influence processes on service quality", Journal of Applied Psychology, Vol. 94 No. 2, p. 371.

Litano, M., Major, D., Landers, R., Streets, V. and Bass, B. (2016), "A meta-analytic investigation of the relationship between leader-member exchange and work-family experiences", The Leadership Quarterly, Vol. 27 No. 5, pp. 802-817.

Locke, E.A. (1976), "The nature and causes of job satisfaction”, in Dunnette, M.D. and Hough, L.M. (Eds), Handbook of Industrial and Organizational Psychology, Consulting Psychologists Press, Palo Alto, Calif.

Lyness, K. and Thompson, D.E. (1997), "Above the glass ceiling? A comparison of matched samples of female and male executives", The Journal of Applied Psychology, Vol. 82 No. 3, pp. 359-375. 
EJMBE 32,1

MacKenzie, S.B., Podsakoff, P.M. and Jarvis, C.B. (2005), "The problem of measurement model misspecification in behavioral and organizational research and some recommended solutions", Journal of Applied Psychology, Vol. 90 No. 4, p. 710.

Madhavi, C. (2015), "Impact of work family conflict on job and life satisfaction", International Journal on Global Business Management and Research, Vol. 3 No. 2, p. 35.

Major, D. and Lauzun, H. (2010), "Equipping managers to assist employees in addressing work-family conflict: applying the research literature toward innovative practice", The Psychologist-Manager Journal, Vol. 13 No. 2, pp. 69-85.

Major, D., Fletcher, T., Davis, D. and Germano, L. (2008), "The influence of work-family culture and workplace relationships on work interference with family: a multilevel model”, Journal of Organizational Behavior, Vol. 29 No. 7, pp. 881-897.

Mas-Machuca, M., Berbegal-Mirabent, J. and Alegre, I. (2016), "Work-life balance and its relationship with organizational pride and job satisfaction", Journal of Managerial Psychology, Vol. 31 No. 2, pp. 586-602.

McDonald, R.P. and Ho, M.H.R. (2002), "Principles and practice in reporting structural equation analyses", Psychological Methods, Vol. 7 No. 1, p. 64.

McDowell, W., Matthews, L., Matthews, R., Aaron, J., Edmondson, D. and Ward, C. (2019), "The price of success: balancing the effects of entrepreneurial commitment, work-family conflict and emotional exhaustion on job satisfaction", International Entrepreneurship and Management Journal, Vol. 15 No. 4, pp. 1179-1192.

Mesmer-Magnus, J. and Viswesvaran, C. (2005), “Convergence between measures of work-to-family and family-to-work conflict: a meta-analytic examination", Journal of Vocational Behavior, Vol. 67 No. 2, pp. 215-232.

Meyer, J. and Allen, N. (1991), “A three-component conceptualization of organizational commitment", Human Resource Management Review, Vol. 1 No. 1, pp. 61-89.

Meyer, J., Morin, A. and Vandenberghe, C. (2015), "Dual commitment to organization and supervisor: a person-centered approach”, Journal of Vocational Behavior, Vol. 88, pp. 56-72.

Michel, J.S., Kotrba, L.M., Mitchelson, J.K., Clark, M.A. and Baltes, B.B. (2011), “Antecedents of workfamily conflict: a meta-analytic review", Journal of Organizational Behavior, Vol. 32 No. 5, pp. 689-725.

Mor Barak, M.E. and Levin, A. (2002), "Outside of the corporate mainstream and excluded from the work community: a study of diversity, job satisfaction and well-being", Community, Work and Family, Vol. 5, pp. 133-157.

Mowday, R., Steers, R. and Porter, L. (1979), "The measurement of organizational commitment", Journal of Vocational Behavior, Vol. 14 No. 2, pp. 224-247.

Mowday, R., Porter, L. and Steers, R. (1982), Employee-organization Linkages: The Psychology of Commitment, Absenteeism, and Turnover, Academic Press, New York, NY.

Mukanzi, C. and Senaji, T. (2017), "Work-family conflict and employee commitment: the moderating effect of perceived managerial support", SAGE Open, Vol. 7 No. 3, pp. 1-12.

Netemeyer, R.G., Boles, J.S. and McMurrian, R. (1996), "Development and validation of work-family conflict and family-work conflict scales”, Journal of Applied Psychology, Vol. 81 No. 4, p. 400.

Ng, T.W.H. and Sorensen, K.L. (2008), "Toward a further understanding of the relationships between perceptions of support and work attitudes: a meta-analysis", Group and Organization Management, Vol. 33, pp. 243-268.

Nohe, C. and Sonntag, K. (2014), "Work-family conflict, social support, and turnover intentions: a longitudinal study", Journal of Vocational Behavior, Vol. 85 No. 1, pp. 1-12.

Odriozola, M. and Baraibar-Diez, E. (2018), "Do work-life balance practices mediate in the relationship between female participation and financial performance?", European Journal of Management and Business Economics, Vol. 27 No. 3, pp. 249-265. 
O’Driscoll, M., Poelmans, S., Spector, P., Kalliath, T., Allen, T., Cooper, C. and Sanchez, J. (2003), "Familyresponsive interventions, perceived organizational and supervisor support, work-family conflict, and psychological strain”, International Journal of Stress Management, Vol. 10 No. 4, pp. 326-344.

Pluut, H., Ilies, R., Curşeu, P.L. and Liu, Y. (2018), "Social support at work and at home: dual-buffering effects in the work-family conflict process", Organizational Behavior and Human Decision Processes, Vol. 146, pp. 1-13.

Podsakoff, P.M., MacKenzie, S.B., Lee, J.-Y. and Podsakoff, N.P. (2003), "Common method biases in behavioral research: a critical review of the literature and recommended remedies", Journal of Applied Psychology, Vol. 88 No. 5, pp. 879-903.

Pohl, S. and Galletta, M. (2017), "The role of supervisor emotional support on individual job satisfaction: a multilevel analysis", Applied Nursing Research, Vol. 33 No. 61, pp. 61-66.

Quick, J. (2013), Preventive Stress Management in Organizations, 2nd ed., American Psychological Association, Washington, DC.

Qureshi, M.A., Bin Ab Hamid, K., Jeihoony, P., Ali, R., Brohi, N.A., Magsi, R. and Shah, S.M.M. (2018), "Is supervisor support matter in job satisfaction? A moderating role of fairness perception among nurses in Pakistan”, Academy of Strategic Management Journal, Vol. 17 No. 6, pp. 1-10.

Qureshi, H., Lambert, E.G. and Frank, J. (2019), "When domains spill over: the relationships of workfamily conflict with Indian police affective and continuance commitment", International Journal of Offender Therapy and Comparative Criminology, Vol. 63 No. 14, pp. 2501-2525.

Roscoe, J.T. (1975), Fundamental Research Statistics for the Behavioral Sciences, 2nd ed., Holt, Rinehart and Winston, New York, NY.

Russo, M., Shteigman, A. and Carmeli, A. (2016), "Workplace and family support and work-life balance: implications for individual psychological availability and energy at work", The Journal of Positive Psychology, Vol. 11 No. 2, pp. 1-16.

Schumacker, R. and Lomax, R. (2004), A Beginner's Guide to Structural Equation Modeling, 2nd ed., Lawrence Erlbaum Associates, Mahwah, NJ.

Selvarajan, T., Cloninger, P. and Singh, B. (2013), "Social support and work-family conflict: a test of an indirect effects model", Journal of Vocational Behavior, Vol. 83 No. 3, pp. 486-499.

Skinner, N.J. and Chapman, J. (2013), Work-life Balance and Family Friendly Policies, Doctoral dissertation, ANZSOG-The Australia and New Zealand School of Government.

Skinner, N. and Pocock, B. (2014), The Australian Work and Life Index 2014: The Persistent Challenge: Living, Working, and Caring in Australian 2014, Centre for Work + Life, University of South Australia, available at: https://apo.org.au/sites/default/files/resource-files/2014-09/apo-nid61996.pdf.

Smith, V., Klein, K. and Ehrhart, M. (2002), "Work time, work interference with family, and psychological distress", Journal of Applied Psychology, Vol. 87 No. 3, pp. 427-436.

Solís, M. (2017), "Moderators of telework effects on the work-family conflict and on worker performance", European Journal of Management and Business Economics, Vol. 26 No. 1, pp. 21-34.

Steiger, J.H. (2007), "Understanding the limitations of global fit assessment in structural equation modelling", Personality and Individual Differences, Vol. 42 No. 5, pp. 893-898.

Sterba, S.K. (2011), "Implications of parcel-allocation variability for comparing fit of item-solutions and parcel-solutions", Structural Equation Modeling: A Multidisciplinary Journal, Vol. 18 No. 4, pp. 554-577.

Tabachnick, B.G. and Fidell, L.S. (1989), Using Multivariate Statistics, 2nd ed., Harper and Row, Cambridge, MA.

Talukder, A., Vickers, M. and Khan, A. (2018), "Supervisor support and work-life balance: impacts on job performance in the Australian financial sector", Personnel Review, Vol. 47 No. 3, pp. 727-744.

Tharenou, P., Donohue, R. and Cooper, B. (2007), Management Research Methods, Cambridge University Press, Melbourne.

Thomas, L. and Ganster, D. (1995), "Impact of family-supportive work variables on work-family conflict and strain: a control perspective”, Journal of Applied Psychology, Vol. 80 No. 1, pp. 6-15. 
EJMBE 32,1

Thompson, C.A., Beauvais, L.L. and Lyness, K.S. (1999), "When work-family benefits are not enough: the influence of work-family culture on benefit utilization, organizational attachment, and work-family conflict”, Journal of Vocational Behavior, Vol. 54 No. 3, pp. 392-415.

Tummers, L.G. and Bronkhorst, B. (2014), "The impact of leader-member exchange (LMX) on workfamily interference and work-family facilitation”, Personnel Review, Vol. 43 No. 4, pp. 573-591.

Turner, N., Hershcovis, M., Reich, T. and Totterdell, P. (2014), "Work-family interference, psychological distress, and workplace injuries”, Journal of Occupational and Organizational Psychology, Vol. 87 No. 4, pp. 715-732.

Vargas-Halabí, T., Mora-Esquivel, R. and Siles, B. (2017), "Intrapreneurial competencies: development and validation of a measurement scale", European Journal of Management and Business Economics, Vol. 26 No. 1, pp. 86-111.

Wayne, J., Casper, W., Matthews, R. and Allen, T. (2013), "Family-supportive organization perceptions and organizational commitment: the mediating role of work-family conflict and enrichment and partner attitude", The Journal of Applied Psychology, Vol. 98 No. 4, pp. 606-622.

Weale, V., Wells, Y. and Oakman, J. (2019), "The work-life interface: a critical factor between work stressors and job satisfaction", Personnel Review, Vol. 48 No. 4, pp. 880-897.

Wilkins, R., Laß, I., Butterworth, P. and Vera-Toscano, E. (2019), The Household, Income and Labour Dynamics in Australia Survey: Selected Findings from Waves 1 to 17 (2019), Melbourne Institute: Applied Economic and Social Research, The University of Melbourne, available at: https://melbourneinstitute.unimelb.edu.au/__data/assets/pdf_file/0011/3127664/HILDAStatistical-Report-2019.pdf.

Yang, J., Bently, J.R., Treadway, D.C., Brouer, R.L., Wallace, A.B., Jeffery, R., Treadway, D.C., Brouer, R.L. and Wallace, A. (2018), "The role of affective commitment and political skill in the work interfering with family (WIF) conflict - voluntary turnover relationship", The International Journal of Human Resource Management, Vol. 29 No. 3, pp. 595-613.

Zheng, C., Kashi, K., Fan, D., Molineux, J. and Ee, M. (2016), "Impact of individual coping strategies and organisational work-life balance programmes on Australian employee well-being", The International Journal of Human Resource Management, Vol. 27 No. 5, pp. 501-526.

\section{Further reading}

Graen, G.B. and Uhl-Bien, M. (1995), "Relationship-based approach to leadership: development of leader-member exchange (LMX) theory of leadership over 25 years: applying a multi-level multi-domain perspective", The Leadership Quarterly, Vol. 6 No. 2, pp. 219-247.

Keeney, J., Boyd, E., Sinha, R., Westring, A. and Ryan, A. (2013), "From 'work-family' to 'work-life': broadening our conceptualization and measurement", Journal of Vocational Behavior, Vol. 82 No. 3, pp. 221-237.

Ngah, N., Ahmad, A., Hamid, T. and Ismail, A. (2010), "The mediating role of work-family conflict in the relationship between supervisor support and job satisfaction", International Journal of Interdisciplinary Social Sciences, Vol. 4 No. 11, pp. 187-197.

\section{Appendix}

Appendix is avaialble at https://www.emerald.com/insight/content/doi/10.1108/EJMBE-03-2020-0056/ full/html

\section{Corresponding author}

Muhammad Ali can be contacted at: m3.ali@qut.edu.au

For instructions on how to order reprints of this article, please visit our website:

www.emeraldgrouppublishing.com/licensing/reprints.htm

Or contact us for further details: permissions@emeraldinsight.com 